\title{
Raskolnikov's Desire for Confession and Punishment
}

\author{
Reyyan Bal \\ International University of Sarajevo
}

Much criticism about Dostoevsky's Crime and Punishment has focused on the variety and ambivalence of Raskolnikov's motives for committing the crime or transgression of the title. Sergei Hackel, in his article "Raskolnikov through the Looking-Glass: Dostoevsky and Camus's L'Etranger", sums up the various motives that have been discussed in relation to Raskolnikov's crime as follows:

In fact, it is the multiplicity of possible motives that makes Raskolnikov so convincing a presence. Was he seeking money to help his family? Or simply seeking money? Was he putting his concept of the Napoleonic superman to the test? Or killing to relieve the tension created by introspection in his claustrophobic room? Was he mentally or physically ill? Tempted by Satan? Was he expressing his resentment against society? Or attempting to bridge the gulf between society and himself by attracting the former's attention? Or by killing, and thus utterly possessing, one of society's representatives? Or seeking punishment to allay some subconscious guilt? Indulging a will to suffer? (196)

Considerably less criticism has focused on Raskolnikov's motives for confessing his crime and accepting punishment, although the greater part of the novel is devoted to this process. Indeed, after the crime committed early on in the plot, the rest of Crime and Punishment deals with Raskolnikov's vacillation between his instinct of self-preservation and urge for confession and punishment, with the eventual triumph of the latter. According to Priscilla Meyer, Dostoevsky planned Crime and Punishment as a confessional novel. As evidence for this, she cites a letter written by Dostoevsky to his brother: 
In a letter to his brother written in 1859, Dostoevsky excitedly reported his intention to write a confessional novel, "ispoved-roman," which he had thought up in prison...to be called The Confession (Ispoved). The commentators to the Collected Works consider that the title refers to Notes from Underground...I dispute their argument...There appears to be insufficient evidence to controvert Grossman's earlier conclusion: "Hints sprinkled throughout Dostoevsky's letters and notebooks show that by 'Confession' he meant the story of Raskolnikov.” (236)

Just like his crime, Raskonikov's confession is also a result of multifarious motives and "has long since become one of the classical episodes in the literature of psychology" (Squires 491). In his work on criminal psychology, Hans Gross describes confession as "a very extraordinary psychological problem" and makes a long yet inexhaustive list of motives behind criminals' confession, everything from vanity, to the desire to receive care and lodgings, to the noble desire to protect someone else, to the pressure of conscience (1-2). In the case of Raskolnikov, it will perhaps be helpful to analyse the motives leading him to his eventual confession(s) in relation to the three planes of experience, the social, the psychological, and the spiritual planes. Raskolnikov is profoundly affected on all three levels of experience as a result of his crime, and these effects are what gradually lead him towards confession.

From the beginning of Crime and Punishment, Raskolnikov is presented as a character who has isolated himself from society. He fears meeting his landlady, dreads coming across any of his friends, and looks on the people around him with scorn. The reasons for this isolation seem to be a curious mixture of pride and projected self-loathing. Raskolnikov is handsome and intelligent, and we later learn that he was a successful law student, but had to give up his studies due to lack of money. Instead of finding ways to earn money and continue his studies, like his friend Razumihin does, Raskolnikov has imprisoned himself in his tiny tomb-like room in a poor neighbourhood and there given vent to neurotic 
thoughts that have further distanced him from society. His article "On Crime" reflects his pride, his disdain of others - the common populace - and his dissatisfaction with the social conditions of his country. According to the article, certain superior, extraordinary individuals, such as Napoleon, have the right to transgress legal and moral boundaries in acts that sacrifice a relatively small number of people to the greater good of the greater number, as advocated by utilitarianism. It becomes evident that Raskolnikov sees himself as capable of being one such superman, and his plan to kill Alyona Ivanovna and use her money to help poor people is based on his wish to prove this to himself. He confesses this to Sonia:

I wanted to become a Napoleon, that is why I killed her ... I ... murdered her, following his example ... I ... resolved ... to build up a completely new career and enter upon a new life of independence ... He who despises most things will be a lawgiver among them and he who dares most of all will be most in the right! So it has been till now and so it always will be ... I...I wanted to have the daring...and I killed her. I only wanted to have the daring, Sonia! That was the whole cause of it!...I know it all now...Understand me! Perhaps I should never have committed a murder again. I wanted to find out then and quickly whether I was a louse like everybody else or a man. Whether I can step over barriers or not, whether I dare stoop to pick up or not, whether I am a trembling creature or whether I have the right. (406)

"Is there, in all literature, a more terrible confession of social impotency than this?” asks Peter Chatham Squires in his article “Dostoevsky's 'Raskolnikov': The Criminalistic Protest".

Raskolnikov's crime is both the result of this social impotency, and the cause of its increase to an unbearable level, for, not only does he discover as soon as he commits the murder that he has failed in his attempt to become a superman, but both this discovery and the nervous state caused by his crime disable him 
from being able to carry out even the simplest social gestures. Following his crime, Raskolnikov becomes seriously ill for days, showing both his physical and psychological weakness, and becomes very nervous in the presence of other people, especially Porfiry Petrovic, but also in the presence of those dearest to him. Although he discovers that he is one of the common multitude, Raskolnikov has erected a seemingly insurmountable barrier between himself and this multitude - including his close friends and family - due to his crime. In a letter to his editor, Dostoevsky remarks that "the feeling of separation and dissociation from humanity which he [Raskolnikov] experiences at once after he has committed the crime, is something he cannot bear" (qtd. in Beebe 157). As long as he protects his freedom by hiding his crime, Raskolnikov will always remain alienated from the people around him. The appearance of his mother and beloved sister Dounia, together with his friend Razumihin - all of whom try to help and support him - serves to emphasize this terrible isolation. "Mother, sister - how I loved them! Why do I hate them now?...I can't bear them near me...I went up to my mother and kissed her, I remember...To embrace her and think if she only knew" (235). These are people that Raskolnikov does not despise, people who he can relate to, but he has made it impossible for himself to relate to them or to accept their help and support. He has become like a louse among them - "Yes, I am certainly a louse" (234) - just as Alyona Ivanovna was a louse in the community. The only way for Raskolnikov to overcome this social impotency and become re-integrated into society is by confessing his crime and accepting his punishment.

In a world that is harsh and unattractive, yet, as he is to discover, neither utterly alien nor entirely incoherent, people turn out to have more significance for him than he expected: "You can't do without us," as Porfiry Petrovich points out to him. His thoughts on the question of a superman morality never liberate him altogether from the claims of alternative moral attitudes, attitudes of which his mother, sister, 
girlfriend constantly remind him. There is a tension within him; and his confession, expiation, and - rather tentatively suggested - regeneration are the way out of this tension. (Hackel 194)

A deeper level for Raskolnikov's desire for confession and punishment is the psychological level. In their discussion about crime, Razumihin harshly criticizes the socialist doctrine, according to which "human nature is not taken into account, it is excluded, it's not supposed to exist" (219). This disregard for human nature is also true for Raskolnikov's theory of crime, at which Razumihin is appalled, expressing his "horror...that you sanction bloodshed in the name of conscience" (225). Razumihin is proven right, and human nature reveals itself in Raskolnikov as soon as he commits the crime. Despite his continual rationalizations of the crime, and despite his denial of his feelings of guilt claiming that he has only transgressed legally and not morally - Raskolnikov does in fact feel guilty. Regardless of her character or her significance, Alyona Ivanovna was a human being, and he killed her brutally; moreover, he also killed the simple, innocent and harmless Lizaveta.

Raskolnikov's initial pride, which convinced him of his superiority to other people, and especially a "louse" like Alyona Ivanovna, rapidly diminishes after his crime. He realizes his own lack of strength and the baseness and crudeness of his crime and the actions following it. He is not at all a superman like Napoleon.

Too late, he emerges from his trance with the realization that the superb Will-to-Dare possessed by the man of Austerlitz and St. Helena is not for him, that he is nothing but a weakling. "I am just such a louse as all the rest." He admits himself to be "vain, envious, malicious, base, vindictive and...well, perhaps with a tendency to insanity." (Squires 484)

Raskolnikov imagines Porfiry Petrovic mocking him on this point - actually projecting his self-mockery onto Porfiry - asking him whether a Napoleon would 
crawl under an old woman's bed to search for her purse (234). This disintegration of his pride and self-worth causes Raskolnikov to feel that it is not worthwhile to protect his freedom; in his own eyes, he is not worth preserving.

As Raskolnikov finds out, committing a crime and escaping punishment for it requires ceaseless energy and strength. For the rest of his life, he will be pursued by the relentless fears and dilemmas caused by his efforts to hide his crime; he will never be free of suspicion and apprehension. Therefore, physical freedom comes at the cost of psychological burden and imprisonment. Raskolnikov realizes that he will not survive much longer under this strain (134). In fact, suddenly feeling clear-headed and determined after his bout of illness, he decides to bring an end to his torture, presumably by confessing: "he had one thought only: 'that all this must be ended today, once for all, immediately" (134). After this resolution, he encounters Zametov in a restaurant and practically confesses to him; he has a change of heart half-way through, however, and pretends to have been joking. Stating that "Dostoevsky embodied his entire philosophy of guilt and redemption in [Raskolnikov]," John D. Simons analyses Raskolnikov's state of mind after the crime as follows:

In preparing the way for Raskolnikov's regeneration, Dostoevsky first showed that Raskolnikov's reaction to the crime was not one of remorse, but an indefinable mood which made him uneasy. Although alone, he had never been able to feel alone; he seemed aware of an uneasy presence near him. It did not frighten him, but greatly annoyed him. The feeling of despair grew in Raskolnikov until it tortured him to delirium. (168)

In a way, confessing his guilt will free Raskolnikov's mind of these dilemmas haunting it. Since his life outside of prison is not really a free one either, with his cell-like room, his poverty and his lack of meaningful occupation, he eventually decides to at least set his mind free, by seeking punishment through confession. 
None of these psychological reasons for his desire for confession are recognized by Raskolnikov consciously. They emerge in his dreams and underlie his thoughts and actions. Ruth Mortimer discusses Dostoevsky's use of dreams in Crime and Punishment in her article "Dostoevski and the Dream Author(s)":

It is in the novel Crime and Punishment that this technique of the dream is presented most artistically and most completely. There are four fully told dreams which concern the chief character, Raskolnikov. Each of these dreams leads into the next, illustrating both the significance of the dream in the complex psychology of a character like Raskolnikov and the use of the dream for dramatic atmosphere. In creating these dreams, Dostoevski has repeated events or reshaped ideas in terms of the unconscious of the character who is dreaming. Thus the succession of dreams forms a psychic pattern of motivation as valid as the course of external episodes. (108)

This "psychic pattern of motivation" is one of the most important factors that eventually lead Raskolnikov to confess and accept punishment. The first dream that Raskolnikov sees before he commits the murder is a foreshadowing of the remorse that he will feel after the crime. In the dream - based on a childhood memory - a drunk, sadistic man beats an old mare to death while the child Raskolnikov looks on in horror. He is incapable of preventing this crime, but he feels great pity because of it, taking the dead horse's head onto his lap and kissing it (49-53). Rahv points out that in the dream "Raskolnikov is both the compassionate little boy and the murderous Mikolka. He is also the nag, himself a victim, which he implies by his remark to Sonya: 'I didn't kill the old woman-I killed myself" (qtd. in Marchant 8). Waking up from the dream, he cries "Good God!...can it be, that I shall really take an axe, that I shall strike her on the head, split her skull open...that I shall tread in the sticky warm blood" (53). Although he ends up actually carrying out these deeds, his feelings during and after the dream foreshadow his feelings after the crime. Mortimer remarks that, 
[T] he terror which Raskolnikov experiences as a child over the death struggles of the helpless mare predicts his loss of control over the act of murder. The early emotions aroused in the dream are still within him. The basic feelings of pity and compassion, natural to the child, must still exist in Raskolnikov if he can suffer them so acutely in a dream. When, at the end of the dream, the boy rushes at Mikolka in a frenzy of hatred, he actually is confronting himself, the mature Raskolnikov, his victim lying at his feet. The conclusion of the dream, the child weeping in his father's arms, suggests the scene near the close of the novel in which Raskolnikov kneels before his mother when he knows he will confess his crime. (111)

In another dream, Raskolnikov's sense of weakness, inadequacy and humiliation after his crime becomes evident. In the dream, he sees himself performing the murder of Alyona once more, but this time no matter how many blows he hits her with the axe, she does not die and laughs at him instead (237).

This dream is concentrated upon Raskolnikov himself performing the act of violence, whereas, in the preceding dreams, the murder was so far repressed that the furious peasant, Mikolka, and Ilya Petrovitch were the assailants. This repression was caused by an unconscious refusal to admit his own crime. The murder dream implies an extremely intricate psychic motivation: at the moment when Raskolnikov is able to recognize his act sufficiently to reproduce it as his own, the final impression is of failure. Here he finds himself incapable of murder, from a purely physical standpoint. Under the blows of the axe, the old woman sits as though made of wood and only laughs at his vicious attempt. The fact, here reduced to its simplest terms, is, in actuality, the growing realization that psychologically Raskolnikov cannot endure the effects of the murder. (113)

Thus, this dream brings to Raskolnikov's consciousness not only the realisation of his humiliation at his weakness, but also his realisation of his act for what it was, 
a violent, meaningless, cowardly deed, and also the fact that he is unable to cope with this reality.

Together, these unconscious psychological motivations produce in Raskolnikov an unconscious desire to be caught. This desire is manifest in several of his actions. One of these is his revisiting of the crime scene. While walking around the city disturbed, he suddenly finds himself there. Since Raskolnikov knows that this act will incriminate him, his involuntarily performing it reveals his unconscious desire to be caught.

Porfiry Petrovic, an expert at criminal psychology, becomes aware of all of these psychological motivations in Raskolnikov, and he uses them and even plays with them to instigate his confession and redemption. He tells Raskolnikov:

It's not merely that he has nowhere to run to, he is psychologically unable to escape me, he-he!...Through a law of nature he can't escape me if he had anywhere to go. Have you seen a butterfly round a candle? That's how he will keep circling and circling round me. Freedom will lose its attractions. He'll begin to brood, he'll weave a tangle round himself, he'll worry himself to death!...He'll fly straight into my mouth and I'll swallow him. (IV.5.289)

Porfiry is masterfully manipulating Raskolnikov. His words act on three levels: they describe general criminal psychology, they describe Raskolnikov's particular psychology and they condition Raskolnikov's future actions.

Inspector Porfiry subjected Rodion to the most terrifying of all methods of inquisition: torture purely mental. He jokes with his prey, he cajoles him. Of course he is "only joking"; but then, you know, a man guilty of a crime can at last find freedom only in prison. Needless to say - so runs on the inspector - he would not dream of accusing Rodion. But doesn't Rodion think that whoever is guilty would be wise to confess and thereby obtain a favourable bargain with the law? (Squires 491) 
Porfiry Petrovic presents Raskolnikov with the path to deliverance from the darkness caused by his psychology, and his intelligence and kindness make Raskolnikov respect him and pay heed to his advice. In fact, Porfiry is not only concerned with catching Raskolnikov, but also with saving him. "His purpose is to convince Raskolnikov that he should surrender and confess the crime, because Porfiry knows that Raskolnikov needs the punishment and suffering to such an extent that, even if he ran away, he would return of his own accord" (Simons 169). Porfiry wants Raskolnikov to confess, not only so that they can punish him, but because he wants Raskolnikov to be saved, morally and psychologically, and the only way is for him to confess and accept punishment for his crime. "When Porfiry says 'Give yourself up and confess,' he is advising Raskolnikov both to give himself up to human law as well as to find faith in God" (Meyer 242).

As has been mentioned, Raskolnikov's psychological dilemmas take place unconsciously, surfacing in his dreams and motivating his actions without him being consciously aware of them. However, these dilemmas also confront him in physical form, through characters that embody the different aspects of Raskolnikov's personality. “Dostoevsky examines the hero's movement toward confession by embodying his motives in different characters" (Meyer 242). Maurice Beebe explains Dostoevsky's technique as follows:

Because his protagonists are usually split personalities, the psychological and philosophical drama in a Dostoevsky novel is expressed in terms of a conflict between opposite poles of sensibility and intelligence, spirit and mind, passiveness and aggressiveness, selfsacrifice and self-assertion...or, sometimes, "good" and "bad." To dramatize this conflict, Dostoevsky often gives his characters several alter egos or doubles, each projecting one of the extremes of the split personality... According to most interpretations of Crime and Punishment, the struggle within Raskolnikov becomes physical, external action as he wavers between Svidrigailov, epitome of self-willed evil, and Sonia, 
epitome of self-sacrifice and spiritual goodness." (1512)

Through his encounters with the two characters, Sonia and Svidrigailov, who embody the polar aspects of his own personality, Raskolnikov is able to see more clearly and concretely the choice before him. One side of his psychology - the side that pushed him towards his crime and that is now motivating him to protect himself by concealing his crime - if followed, will lead him to become like Svidrigailov. The other side - the side that led him to save a child from fire, to give the last money in his pocket to the Marmeladovs, and the side that is urging him towards confession - will lead him to become like Sonia. It is through these characters that Raskolnikov is able to consciously confront the unconscious aspects of his personality.

Both Sonia and Svidrigailov are transgressors like Raskolnikov. Unlike Raskolnikov, however, both of these characters seem to be free from feelings of guilt - as, indeed, Raskolnikov should have been had he been a superman. Yet, both Sonia and Svidrigailov's reasons for transgression and their reasons for not feeling guilty are in complete contrast to one another. Sonia transgresses physically, but never spiritually, with the sole motive of feeding her starving family. This is the reason for her freedom from guilt: she is certain that she will be forgiven because hers is an act of self-sacrifice. Svidrigailov, on the other hand, transgresses due to his self-interest, his desires and his disregard for what happens to other people in the fulfilment of those desires. He does not feel guilty, because he is amoral, he has completely suppressed his conscience. Even his acts of kindness prior to his suicide are easy acts, requiring little effort and sacrifice, and giving him the self-satisfaction of having performed them.

Svidrigailov and Sonia represent the psychological dilemma that Raskolnikov is struggling with: he will be freed from his feelings of remorse and uncertainty, either by succeeding in repressing his conscience, or by confessing, receiving punishment, and thus making peace with his conscience. Edward 
Wasiolek, in discussing the structure of Crime and Punishment, argues that "Sonia and Svidrigaylov stand in antithetical relationship and that both are probably objectifications of the opposing moral principles that Raskolnikov carries within him" (132). According to Wasiolek,

He can now proceed to organize his life cynically - for the naive self-confidence in his power to organize his life wholly according to will and reason has been destroyed - according to a new plan based on these principles; or he can organize it according to the other set of principles within him, which had been suppressed in the first half [of the novel] but which had welled up on a number of occasions to oppose the ruling principles. He can in short follow the path of Svidrigaylov or of Sonia. Sonia represents the negation of the principle that had led to the murder of the old woman; Svidrigaylov, the "man of bronze" who can do evil without pangs of conscience, represents the ultimate disastrous consequences of such a principle. (133)

Likewise, Peter Marchant describes Svidrigailov as "the angel of darkness, representing skepticism, sybaritism, and hopeless rationalism" and Sonia as "the personification of Grace through which Raskolnikov is saved" (5). The personification of the paths before him makes it easier for Raskolnikov to see the implications of both and - because he is disgusted by Svidrigailov and drawn to Sonia - to choose the path of redemption through confession and punishment.

Raskolnikov's choice of the path of Sonia leads him towards the deepest level of his eventual desire for confession and punishment, the spiritual level. According to Alexandra Rudicina, Crime and Punishment follows the archetypal pattern of transgression followed by a fall and suffering, followed by rebirth. "This underlying pattern reflects the archetypal scheme of rebirth through transgression followed by suffering, or expiation, which informs the central myth of Christianity, the Fall of Man and his Redemption" (1065). Fittingly, 
Raskolnikov's sin is pride; he believes that he has the right to take the life of another human being, based on his interpretation of her as worthless "vermin".

His wish to rob and murder the old pawnbroker that he may administer justice by distributing her ill-gotten riches to the more deserving poor or, more probably, that he may finance the education that is to make him a benefactor of mankind...is rooted in Raskolnikov's dominating characteristic, the egoistic pride that makes him want to play God. (152)

The gradual disintegration of this pride during his suffering after his transgression is an essential part of Raskolnikov's path towards redemption and rebirth. The most important step he must take in order to be redeemed is that of confession; only after he confesses his crime and truly feels remorse for it can he be reborn. The Eastern Orthodox tradition of confession is different from that of the Catholic Church:

Within the Eastern Orthodox and Eastern Catholic churches, it is understood that the Mystery of confession and repentance has more to do with the spiritual development of the individual and much less to do with purification. Sin is not seen as a stain on the soul, but rather a mistake that needs correction. In general, the Orthodox Christian chooses an individual to trust as his or her spiritual guide. In most cases this is the parish priest, but may be...any individual, male or female, who has received permission from a bishop to hear confession. This person is often referred to as one's "spiritual father" or "spiritual mother". Once chosen, the individual turns to his spiritual guide for advice on his or her spiritual development, confessing sins, and asking advice. Orthodox Christians tend to confess only to this individual and the intimacy created by this bond makes the spiritual guide the most qualified in dealing with the person, so much so that no one can override what a spiritual guide tells his or her charges. What is confessed to one's spiritual guide is protected by the same seal as would be any priest 
hearing a confession...Orthodox understand that the confession is not made to the priest, but to Christ, and the priest stands only as witness and guide. (Internet 1)

This sheds light on the relationship between Raskolnikov and Sonia. Despite being a prostitute, Sonia is portrayed as a saintly character throughout the novel. Raskolnikov is first attracted to her "because of her great suffering", as he tells her, and also because he sees her as a fellow transgressor who will therefore be able to understand him. From the moment their relationship begins, Sonia has a redeeming influence on Raskolnikov; she represents the compassionate, altruistic, loving aspects of his own character and helps to strengthen these characteristics. The first time Raskolnikov goes to her apartment, he asks her to read the story of the raising of Lazarus from the New Testament, a story which has been reminded to him purposefully by Porfiry. This scene is a foreshadowing of Raskolnikov's eventual rebirth through the influence of Sonia. When Raskolnikov decides to confess his crime to Sonia, he effectually chooses her as his "spiritual mother."

As Raskolnikov's spiritual mother, not only does Sonia bring about his spiritual salvation, but she also assists his social and psychological redemption. "It is Sonia who understands Raskolnikov and points the way to redemption. He must go and stand at the crossroads, bow down, kiss the earth which he has defiled, and then bow down to all the world and say that he is a murderer" (Simons 169). In this one gesture that she tells Raskolnikov to perform, Sonia is aiming at his making peace spiritually, psychologically and socially. Spiritually, he will have crushed his pride and asked the earth for forgiveness for his sin. Psychologically, he will have honestly confronted himself, accepted that what he did was wrong, and relieved himself of his psychological burden by openly declaring this. Socially, he will have broken the wall that he has constructed between himself and other people by confessing his crime and accepting punishment for it. Raskolnikov does not carry out this gesture; he is not yet ready 
for it psychologically. However, he does surrender himself to the police and accept his punishment, even refusing to defend himself during his trial.

Thus, before the beginning of his imprisonment, Raskolnikov has confessed spiritually, to Sonia, and socially, to the police. However, neither of these is complete before his psychological confession, his full acceptance, unconsciously as well and consciously, of the fact that what he did was wrong. Even in prison, Raskolnikov still declares that his crime was a mistake and not a sin and that his confession was due to weakness and not repentance, and he is once again socially alienated from the other prisoners. Sonia is still with him, however, providing a link between him and his family and also between him and the other prisoners, who all admire her. With Sonia's continued support, the psychological confession finally takes place, appropriately, via a dream. This is the final dream of the novel, the allegorical dream in which he sees society inflicted with a plague - a virus that causes people to think that they are the sole possessors of truth and to tear each other apart as a result of this. The dream makes it evident that, unconsciously, Raskolnikov has finally realised how dangerous and damaging his previous theories had been. After this dream, while sitting hand in hand with Sonia, Raskolnikov experiences the moment of recognition that constitutes his full psychological confession, and as a result, he breaks into tears, embraces Sonia, and realises that he loves her; that evening, he takes out the New Testament that she had given him from under his pillow. Raskolnikov's psychological acceptance has finally brought about his full redemption, socially, psychologically, and spiritually. Sonia, his spiritual mother, has been the catalyst that has brought this about.

In conclusion, in Crime and Punishment we witness Raskolnikov's process of confession and his gradual transformation after his act of transgression. "We find that Raskolnikov goes from pride to humility, hate to love...and from separation from his fellow men to communion with them" (Wasiolek 132). In short, we witness his spiritual, psychological, and social transformation. This transformation is both the cause and result of his eventual confession. The 
complex and multi-faceted motives for Raskolnikov's confession are rooted in these three planes of his existence and his confession and punishment serve to relieve the tensions that he experiences in these areas. Only after he has accepted his crime and sin on all three of these planes - social, psychological, and spiritual - and accepted the punishment and suffering that come as a result of it, is he able to be raised from the dead like Lazarus and be reborn. "But that is the beginning of a new story," as Dostoevsky writes, "the story of the gradual renewal of a man, the story of his gradual regeneration, of his passing from one world into another, of his initiation into a new unknown life" (Epilogue 462).

\section{Works Cited}

\section{Primary Source:}

Dostoevsky, Fyodor. Crime and Punishment. Trans. Constance Garnett. Kent: Wordsworth, 2000.

\section{Secondary Sources:}

Beebe, Maurice. "The Three Motives of Raskolnikov: A Reinterpretation of Crime and Punishment." College English, Vol. 17, No. 3. (Dec., 1955), pp. 151-158. <http://links.jstor.org/sici?sici=0010-0994\%28195512\%2917\%3A3\%3C151\% 3ATTMORA\%3E2.0.C0\%3B2-6>

Gross, Hans Criminal Psychology: A Manual for Judges, Practitioners, and Students. Trans. Horace M. Kallen. New Jersey: Patterson Smith. $<$ http://emotional-literacy-education.com/classic-books-onlinea/crmsy10.htm>

Hackel, Sergei. "Raskolnikov through the Looking-Glass: Dostoevsky and Camus's L'Etranger." Contemporary Literature, Vol. 9, No. 2 (Spring, 1968), pp. 189-209. <http://www.jstor.org/stable/1207491>

Marchant, Peter. "The Mystery of Lizaveta." Modern Language Studies, Vol. 4, No. 2. Autumn, 1974), pp. 5-13. $<$ http://links.jstor.org/sici?sici=0047-7729\%28197423\%294\%3A2\%3C5\% 3ATMOL \%3E2.0.CO\%3B2-C>

Meyer, Priscilla. “Crime and Punishment and Jules Janin’s La Confession." Russian Review, Vol. 58, No. 2 (Apr., 1999), pp. 234-243. <http://www.jstor.org/stable/2679577> 
Mortimer, Ruth. "Dostoevski and the Dream." Modern Philology, Vol. 54, No. 2 (Nov., 1956), pp. 106-116.

<http://www.jstor.org/stable/435051>

Rudicina, Alexandra F. "Crime and Myth: The Archetypal Pattern of Rebirth in Three Novels of Dostoevsky." PMLA, Vol. 87, No. 5. (Oct., 1972), pp. 1065-1074. $<$ http://links.jstor.org/sici?sici=00308129\%28197210\%2987\%3A5\%3C1065\%3 ACAMTAP\%3 E2.0.CO\%3B2-4>

Simons, John D. "The Nature of Suffering in Schiller and Dostoevsky." Comparative Literature, Vol. 19, No. 2 (Spring, 1967), pp. 160-173. <http://www.jstor.org/stable/1769432>

Squires, Paul Chatham. “Dostoevsky's 'Raskolnikov': The Criminalistic Protest.” Journal of Criminal Law and Criminology (1931-1951), Vol. 28, No. 4 (Nov. - Dec., 1937), pp. 478-494.

<http://www.jstor.org/stable/1136780>

Wasiolek, Edward. "On the Structure of Crime and Punishment." PMLA, Vol. 74, No. 1 (Mar., 1959), pp. 131-136.

< http://www.jstor.org/stable/460394>

\section{Internet Sources:}

1. "Confession." Wikipedia, The Free Encyclopedia. 30 Nov 2007, 15:32 UTC. Wikimedia Foundation, Inc. 4 Dec 2007.

<http://en.wikipedia.org/w/index.php?title=Confession\&oldid=174843628> 